\title{
POTRET PERJUANGAN KEMERDEKAAN INDONESIA \\ DALAM NOVEL ANAK TERBITAN BALAI PUSTAKA \\ TAHUN 1976-1996
}

\section{THE POTRAIT OF INDONESIA'S INDEPENDENCE STRUGGLE IN CHILDREN NOVEL PUBLISHED BY BALAI PUSTAKA IN 1976-1996}

\author{
Latief S. Nugraha \\ Balai Bahasa Provinsi Daerah Istimewa Yogyakarta \\ I Dewa Nyoman Oka No. 34, Yogyakarta \\ Pos-el: harjomartono89@gmail.com
}

\begin{abstract}
The research examines children novels with history genre published by Balai Pustaka in 1976-1996. This research is conducted to find out the formula. This research stands on John G. Cawelti genre review. The results of the research show that children novels at Balai Pustaka use various formulas with the same basic theme -a fighting spirit to fight back colonial. The historical approach has strengthened Balai Pustaka's children novels as generic fiction works. At that time, the children novels were built from the high tension between two worlds; ideal world and real world as imaginary world. There are different approaches in solving the problems from each period, and authors, although most of the formula used have 'failure' because of the old composition and theme usage.
\end{abstract}

Keywords: Balai Pustaka, children novel, colonial history, genre, formula

\begin{abstract}
Abstrak
Penelitian ini mengkaji novel-novel dengan label novel anak terbitan Balai Pustaka tahun 1976-1996 dengan genre sejarah. Kajian ini dilakukan untuk mengetahui formula novel anak genre sejarah terbitan Balai Pustaka tahun 1976-1996. Kajian berpijak pada tinjauan genre John G. Cawelti. Hasil kajian menunjukkan bahwa novel-novel anak genre sejarah (kolonial) Balai Pustaka menggunakan formula yang beragam, namun dengan tema dasar sama, yakni semangat perjuangan melawan kolonial. Pendekatan sejarah yang digunakan memperkuat novel-novel anak terbitan Balai Pustaka sebagai fiksi-fiksi ciptaan yang bersifat generik. Novel-novel anak periode tersebut terbangun dari ketegangan antara dua dunia, yakni dunia ideal dan dunia nyata sebagai dunia imajiner. Terdapat perbedaan kecenderungan penyelesaian masalah dari masing-masing periode dan pengarang, meski rata-rata formula cerita yang digunakan mengalami 'kegagalan' dengan menggunakan komposisi dan tema yang sudah klise.
\end{abstract}

Kata Kunci: Balai Pustaka, novel anak, sejarah kolonial, genre, formula 


\section{Pendahuluan}

Penjajahan yang dilakukan bangsa Eropa memberikan banyak pengaruh terhadap bangsa-bangsa bekas jajahannya. Penjajahan merupakan pengalaman kelam yang pernah dialami dalam sejarah peradaban manusia di dunia. Satu hal yang menjadi cita-cita besar atas penjajahan adalah kemerdekaan.

Kemerdekaan politik yang diperoleh oleh bangsa Barat (Eropa) secara meluas terjadi setidaknya sejak berakhirnya Perang Dunia II, dan membuat bangsa-bangsa yang bersangkutan kehilangan kepekaan terhadap masih berlangsungnya penjajahan-penjajahan kultural dari bangsa-bangsa penjajah tersebut (Faruk, 2007:1). Sebagaimana yang dialami oleh Indonesia, proklamasi kemerdekaan dilangsungkan pada tanggal 17 Agustus 1945, tetapi baru mendapat pengakuan dari dunia pada tahun 1949. Menilik persoalan tersebut, dalam kenyataannya perjuangan kemerdekaan bangsa Indonesia yang berlangsung setidaknya sejak awal abad XX sangat erat berhubungan dan bahkan dimulai dengan perjuangan kebahasaan (Faruk, 2007:25).

Kesadaran berbahasa bagi bangsa Indonesia muncul pada periode 1920-an (Rosidi, 1964:7). Berbarengan dengan kesadaran untuk berbahasa, muncul pula kesadaran berbangsa, bahkan bernegara. Sumpah Pemuda pada 28 Oktober 1928 merupakan wujud jejak kebudayaan yang berkembang pada masa kolonial hingga semangat nasionalisme oleh para pemuda yang mengatasnamakan "putra-putri Indonesia". Teks Sumpah Pemuda sebagai "karya sastra" tentu mengandung nilai-nilai semangat mengenai kesadarankesadaran nasionalitas pada masa itu. Hal tersebut disusul dengan kelahiran banyak karya sastra dari tangan para sastrawan yang memiliki semangat nilai nasionalisme.
Novel adalah salah satu dari karya sastra yang menjadi wadah dan wujud dari semangat nasionalisme pada masa itu. Novel sebagai sebuah karya sastra tidak lahir begitu saja tanpa adanya ketegangan antara dunia ideal yang mengandung totalitas dengan realitas sosial yang mengandung fragmentaris. Ketegangan kedua hal tersebut terjadi terus-menerus dalam perkembangan novel-novel Indonesia. Novel sebagai respons yang sekaligus merepresentasikan sebuah model kehidupan, tentunya akan memperlihatkan pengaruh atau bahkan keberpihakan terhadap kenyataan.

\section{Ketika} membicarakan perkembangan novel di Indonesia, tentu kita tidak akan lepas dari novel-novel zaman kolonial yang pada masa itu dibidani oleh Balai Pustaka. Tahun 1908 pemerintah kolonial Belanda mendirikan Commissia voor de Inlandsche School en Volkslectuur atau Komisi untuk Bacaan Sekolah Bribumi dan Bacaan Rakyat. Hal tersebut bertujuan untuk memerangi keberadaan bacaan liar pada awal abad ke-20 yang berisikan ideologi-ideologi tertentu. Dari komisi tersebut kemudian pada tahun 1917 pemerintah kolonial Belanda mendirikan Kantoor voor de Volkslectuur atau Kantor Bacaan Rakyat yang diberi nama Balai Pustaka. Pada garis besarnya buku-buku terbitan Balai Pustaka ketika itu dibagi menjadi tiga, yakni buku untuk anak-anak, buku hiburan dan pengetahuan dalam bahasa daerah, dan buku-buku pengetahuan dalam bahasa Melayu yang kemudian menjadi bahasa Indonesia (Eneste, 1988:6).

Di situlah peran Balai Pustaka dalam perkembangan kesusastraan modern di Indonesia. Buku-buku sastra, novel-novel masa awal Indonesia diterbitkan oleh Balai Pustaka. Di tahun 1920-an Balai Pustaka menunjukkan tajinya dengan menerbitkan buku-buku 
(yang dianggap) bermutu, termasuk buku-buku sastra karya para pengarang pribumi. Tonggak sastra Indonesia modern itu ditandai dengan terbitnya novel Azab dan Sengsara karya Merari Siregar pada tahun 1920. Pada tahun 1920-an banyak novel Indonesia yang diterbitkan oleh Balai Pustaka. Hal tersebut didukung oleh kenyataan bahwa Balai Pustaka adalah satu-satunya penerbit buku yang ada di Indonesia waktu itu. Merujuk pada novel-novel terbitan Balai Pustaka seperti yang sudah disebutkan, yakni Azab dan Sengsara (1920), Sitti Nurbaya (1922) karya Marah Rusli, Salah Asuhan (1928) karya Abdul Muis, Salah Pilih (1928) karya Nur Sutan Iskandar, dan lainnya (Eneste, 1988:7). Tidak mengherankan jika kemudian nama Balai Pustaka merujuk pada nama badan penerbitan, dan sebagai nama suatu periode dalam sastra Indonesia, yakni Angkatan Sastra Balai Pustaka.

Novel-novel Indonesia Tradisi Balai Pustaka masa kolonial identik dengan genre roman. Hal tersebut merupakan pengaruh yang datang dari Barat (Eropa), dan seperti diketahui bahwa Balai Pustaka merupakan penerbitan milik Belanda. Kenyataan tersebut mempertegas bahwa penguasa selalu menang dan sejarah selalu berpihak kepadanya. Keberadaan Balai Pustaka menjadi ukuran gengsi sastra Indonesia saat itu. Bahasa yang digunakan Balai Pustaka dianggap bahasa paling tinggi budayanya. Ia menjadi ikon kebudayaan elit, mencitrakan kesimpulan orang terhormat, terpelajar, dan paling berjasa dalam pengembangan sastra, bahasa dan kebudayaan di Indonesia (Mahayana, 2012:189).

Novel-novel terbitan Balai Pustaka merupakan novel-novel kontemporer yang tidak berpretensi untuk mengklarifikasi sejarah kebudayaan, bahkan tidak ada upaya untuk menciptakan kebanggaan terhadap budaya Indonesia. Kisah percintaannya menjadi ruang negosiasi serta kontemplasi dalam menyikapi berbagai isu keindonesiaan saat itu secara lebih luas. Meskipun demikian, novel bagaimanapun bentuk dan mutunya adalah karya sastra (Sumardjo, 1982:13).

Formula atas novel-novel Indonesia tradisi Balai Pustaka persinggungan antarberbagai fakta dan latar belakang sosial masyarakat sebagai bentuk tematis dalam melihat aspek kebangsaan. Dari hal tersebut dapat dilihat sebuah usaha penguatan semangat kebangsaan dari berbagai perspektif yang secara umum yang kompleks. Asumsi tersebut menjadi langkah awal untuk meneliti berbagai relasi dalam novel tradisi Balai Pustaka untuk menemukan formula-formula genre sejarah kolonial yang digunakan.

Balai Pustaka mendominasi penerbitan buku sastra di Indonesia hingga masuknya tentara Jepang ke Indonesia tahun 1940-an. Pada masa pendudukan Jepang, Balai Pustaka tidak banyak menerbitkan buku-buku sastra karena waktu itu Balai Pustaka menjadi organ pemerintahan Jepang. Setelah Indonesia merdeka barulah Balai Pustaka meraih zaman keemasannya. Hal tersebut terjadi sekitar tahun 1948 sampai dengan pertengahan tahun 1950-an, yakni ketika Balai Pustaka dipimpin oleh L. St. Pamoentjak. Balai Pustaka yang kala itu bekerja sama dengan pengarangpengarang Indonesia, seperti H.B. Jassin, Idrus, M. Taslim Ali, dan Utuy T. Sontani kembali mendominasi penerbitan buku-buku sastra di Indonesia (Eneste, 1988:8).

Selepas tahun 1950-an, peranan Balai Pustaka tidak begitu menonjol dalam penerbitan buku-buku sastra. Hal yang mendasari persoalan tersebut adalah sejak pertengahan tahun 1950-an status Balai Pustaka selalu berubah-ubah, 
sesuai dengan kebijakan Menteri Pendidikan dan kebudayaan RI. Persoalan tersebut berlangsung hingga akhir tahun 1970-an. Dengan masuknya Subagio Sastrowardoyo ke Balai Pustaka sejak awal tahun 1980-an, Balai Pustaka mulai aktif kembali dalam menerbitkan buku-buku sastra, di samping juga terus menerbitkan buku-buku untuk pelajaran sekolah dasar hingga sekolah menengah atas. Namun, peranan Balai Pustaka tidak lagi sehebat tahun 1920-an, 1930-an, atau tahun 1948 sampai dengan 1950-an. Hal tersebut disebabkan oleh bermunculannya penerbit-penerbit buku swasta di Indonesia dengan buku-buku yang lebih berkualitas.

Lebih lanjut dapat dilihat bahwa buku-buku sastra terbitan Balai Pustaka lebih mengarah kepada proyek untuk pendidikan dengan sasaran sekolahsekolah. Balai Pustaka tidak lagi menjadi penerbit buku bergengsi seperti pada masa keemasannya. Hal yang terjadi justru terbalik, penulis-penulis untuk buku-buku Balai Pustaka adalah penulispenulis yang tidak dikenal sebagai sastrawan atau dalam kata lain karyakarya mereka tidak pernah dibicarakan dalam pembahasan mengenai sastra di Indonesia. Namanya tidak pernah disebut dalam pembahasan sastra, apalagi karyakaryanya. Hal yang ironis, ketika pada masa awal berdirinya Balai Pustaka memunculkan karya-karya yang dianggap kanon lantas kemudian karyakaryanya justru sama sekali tidak mendapat perhatian dari masyarakat, dalam hal ini adalah masyarakat sastra. Fenomena tersebut dalam kata lain bahwa karya-karya sastra yang diterbitkan Balai Pustaka belakangan diarahkan sebagai buku materi pendidikan. Keberadaan Balai Pustaka yang kemudian berdiri 'di bawah' Kementerian Pendidikan dan Kebudayaan seolah menjadi terlepas dari keterlibatannya dengan sastra. Buku- buku yang diterbitkan pun tak jarang menjadi buku-buku yang mendapat label sebagai buku materi ajar di sekolahsekolah dari Pusat Perbukuan.

Untuk itu, akan dilihat sisi lain buku-buku terbitan Balai Pustaka dalam novel-novel anak bergenre sejarah kolonial terbitan tahun 1976 sampai dengan 1996. Fokus kajian dibatasi pada novel anak terbitan Balai Pustaka yang mempunyai keterkaitan dengan isu sejarah perjuangan Indonesia melawan Kolonial. Novel-novel anak tersebut adalah Pertempuran Ambarawa (1976) karya A. Soeroto, Sulawesi Berdarah (1976) karya Saadi AS., Lembah di Kaki Bukit (1983) kaya Muh. Sunardiyanto, Pejuang-pejuang Ulet di Lereng Sumbing (1985) karya Suprapto HP., Wonakaka (1993) karya Djoko Dwinanto, dan Pejuang Kecil di Bumi Irian (1996) karya Bagin.

Genre sejarah kolonial dalam novel Indonesia terbitan Balai Pustaka tersebut akan dibandingkan sehingga akan dapat dilihat perkembangan-perkembangan dari kecenderungan yang ada. Kondisi tersebut merupakan sebuah fenomena yang menarik untuk ditelisik, mengingat Balai Pustaka memiliki sejarah yang panjang dalam penerbitan buku-buku sastra juga melihat fenomena bahwa tidak ada lagi nama-nama sastrawan yang bermunculan dari menerbitkan buku di Balai Pustaka selain nama-nama besar sastrawan Angkatan Balai Pustaka yang karyanya terus direproduksi hingga kini. Analisis sederhana dari struktur (konstruksi) formula tersebut diharapkan mampu digunakan untuk menemukan komposisi dan perubahan bentuk yang terjadi dalam pola-pola yang digunakan pengarang pada novel-novel Balai Pustaka dalam kurun waktu tahun 1970an hingga 1990-an tersebut. 


\section{Teori}

Secara konvensional terkait dengan dunia sastra, genre dapat dipahami sebagai klasifikasi terhadap berbagai bentuk yang lahir dalam sebuah karya sastra, misalnya puisi, prosa, dan drama. Dengan demikian, apa yang dipahami tentang genre dalam karya sastra masih sebatas kepada pemahaman umum dalam tiga jenis karya tersebut. Perumusan genre berpijak pada konsep strukturalisme yang melihat teks sebagai sebuah relasi atau hubungan-hubungan struktur antara satu elemen dengan elemen lain sehingga teks tersebut membentuk kesatuan yang padu, otonom dan bisa diterima sebagai sebuah konstruksi karya. Dalam perkembangannya, genre sudah mengalami bermacam perluasan, baik itu variasi maupun penentuan genre. Kondisi tersebut diakibatkan oleh berbagai macam faktor yang ada dalam sebuah struktur teks sastra. Pertimbangan penentuan genre bisa dilihat dari faktor tema, tokoh, metode penceritaan dan lain sebagainya. Wellek dan Warren (1995:300) menyatakan bahwa genre adalah pengelompokkan karya-karya sastra secara teoretis berdasarkan pada bentuk luar (majas atau struktur khusus) dan bentuk dalam (sikap, nada, tujuan, subyek, dan audiens). Aristoteles dan Horace memberikan dasar klasik untuk perkembangan genre, yaitu dua jenis utama sastra, tragedi dan epik.

Dalam penelitian ini kajian genre yang digunakan mengacu pada penelitian genre yang dilakukan oleh Cawelti. Istilah genre lebih sering muncul dalam kritik fiksi populer daripada fiksi serius. Meskipun banyak dibicarakan dan diteliti, kesepakatan tentang arti genre lebih sedikit dibandingkan dengan pertentangannya, karena sifat genre sering berubah. Cawelti (dalam Adi, 2011:198) merumuskan bahwa genre adalah klasifikasi yang muncul berdasarkan dengan isi cerita (narasi) di dalam teks karya. Genre sangat tergantung dengan berbagai aspek yang melekat pada narasi dan struktur yang ada dalam teks. Kondisi tersebut juga dipengaruhi oleh audiens (pembaca) yang berinteraksi langsung dengan teks sastra. Artinya, aspek yang terlihat dalam penelitian genre harus memahami aspek sejarah, tema, arketip, dan minat pembaca. Ditekankan oleh Cawelti bahwa konvensi-konvensi menyajikan gambaran dan arti yang sudah akrab bagi audience dan konvensi tersebut menekankan kesinambungan nilai; invensi-invensi merupakan persepsi atau arti baru yang belum kita sadari sebelumnya. Fungsi keduanya penting bagi budaya. Konvensi membantu menciptakan kestabilan budaya, sedangakan invensi membantu merespon keadaan yang berubah dan memberikan informasi baru tentang dunia (dalam Adi, 2011:205). Hal tersebut berarti bahwa kemunculan berbagai konsep dan klasifikasi genre dalam suatu karya sangat dipengaruhi oleh formula yang ada dalam karya tersebut.

Formula-formula yang menyusun suatu teks dalam karya sastra menentukan aspek yang dominan dan menonjol untuk penentuan genre. Menurut Cawelti (1976:30), asumsi dasar teori evolusi sastra formula adalah polapola literer konvensional karya karena pola-pola tersebut dimasukan ke dalam tatanan konvensional yang efektif bermacam-macam ketertarikan dan fokus kultural dan artistik kultural dan artistik yang ada. Berdasar pada pernyataan tersebut, dapat dikatakan bahwa dalam mengungkap formula sebuah karya sastra harus dicari nilai budaya yang menjadi karakteristiknya dengan dialektika yang sesuai.

Dalam novel Indonesia, terdapat jenis novel yang ceritanya diambil berdasarkan kejadian sejarah. Misalnya novel Surapati, karya Abdul Muis dan 
Hulubalang Raja karya Nun Sutan Iskandar, bisa dikatakan sebagai novel bergenre sejarah. Kondisi tersebut disimpulkan dari unsur sejarah yang muncul sebagai latar dalam teks tersebut. Selain itu juga klasifikasi genre sejarah mencakup aspek yang ada sebagai bagian yang membahas realitas historis, ruang dan waktu yang kontekstual dengan tokoh maupun sosok sebagai tema utama cerita.

Berdasarkan dari ciri dan penjelasan teoretis, karya novel yang disajikan dalam penelitian ini diketahui bergenre sejarah — dalam hal ini sejarah, serta perkembangan genre tersebut dalam beberapa periode kesusastraan Indonesia. Dari situ akan dilihat aspek-aspek naratifnya secara umum, dalam rangka melihat kecenderungan unsur formula yang digunakan maupun variasi dalam novel tersebut. Selain itu akan dilihat pula konvensi dan invensi penyajian gambaran dan persepsi baru yang ada dalam novel-novel tersebut.

\section{Pembahasan}

Novel yang dibahas adalah karya sastra terbitan Balai Pustaka dengan label "novel anak" karya para pengarang yang barangkali sampai saat ini tidak pernah menyandang nama sebagai sastrawan. Novel-novel karya pengarang-pengarang tersebut diarahkan oleh Pusat Perbukuan (Pusbuk) sebagai karya sastra yang mengandung nilai-nilai semangat nasionalisme terkait bahwa novel-novel ini digunakan sebagai bahan ajar di sekolah-sekolah. Berdasar fenomena tersebut, dipilihlah 6 (enam) novel yang bergenre sejarah (kolonial) terbitan Balai Pustaka. Keenam novel ini merupakan novel yang diterbitkan dari periode 1970an hingga periode 1990-an, tepatnya tahun 1976 sampai dengan tahun 1996. Karya novel yang disajikan dalam kurun waktu yang berlainan secara periodik tersebut merupakan sebuah usaha dalam rangka melihat kontinyuitas maupun perkembangan umum novel dalam kesastraan Indonesia modern.

Secara umum novel-novel anak terbitan Balai Pustaka kurun waktu tersebut berisi cerita mengenai peristiwa perjuangan Indonesia menuju 'kemerdekaan'. Hal tersebut bisa disimpulkan dari kisah perjuangan melawan Jepang dan sekutu yang dipimpin Jendral Sudirman dalam novel Pertempuran Ambarawa; kisah kepahlawanan Robert Wolter Monginsidi yang berjuang sampai ajalnya untuk kemerdekaan bangsanya dalam novel Sulawesi Berdarah; kisah Perang Diponegoro dengan semangat para remaja dan pemuda dalam Lembah di Kaki Bukit; kisah seorang anak yang ikut berjuang di sisi tentara Republik untuk meraih kemerdekaan dalam novel Pejuang-pejuang di Lereng Sumbing; kisah Wonakaka seorang pejuang di daerah Kodi dan Pulau Sumba dalam novel Wonakaka; dan kisah pengorbanan Kawon seorang anak berusia 13 tahun dalam perjuangan membebaskan Irian Jaya dari belenggu penjajah dalam novel Pejuang Kecil di Bumi Irian. Kesamaan konsep cerita mengenai perjuangan melawan penjajah tersebut menjadi benang merah dalam menganalisis secara lebih sepesifik, terkait dengan kondisi struktur maupun tematisnya.

\subsection{Formula Novel Anak Genre Sejarah Terbitan Balai Pustaka Tahun 1970-an}

Pembahasan sederhana ini akan dimulai dari periode periode 1970-an. Novel yang akan dibahas terkait dengan periode ini adalah Pertempuran Ambarawa karya A. Soeroto (1976) dan Sulawesi Berdarah karya Saadi AS. (1976). Berikut sinopsis kedua novel tersebut:

Novel Pertempuran Ambarawa karya A. Soeroto menceritakan kisah setelah hari kemerdekaan 17 Agustus 
1945, tentang dua orang sahabat bernama Bambang dan Tukijo, yang berhasil menyelamatkan diri dari kekejaman Jepang dan keluar dari Semarang dengan tujuan ke Purworejo. Tepat tanggal 27 Oktober 1945 kedua sahabat itu berhasil menempuh perjalanan jauh hingga hampir sampai di kota Magelang. Di tengah perjalanan mereka berhenti untuk beristirahat. Semarang telah porak poranda. Banyak korban berjatuhan akibat amukan Jepang. Pada saat itu, tiba-tiba dari kejauhan tampak arakarakan kendaraan. Arak-arakan itu adalah pasukan sekutu yang berhasil melumpuhkan pasukan Jepang. Setelah arak-arakan itu habis, ternyata masih ada satu mobil lagi yang tertinggal di belakang dan tepat di hadapan mereka ban mobilnya meledak. Bambang dan Tukijo akhirnya melanjutkan perjalanan bersama jip yang dikemudikan oleh Letnan Kasim itu sampai Magelang.

Sebelum ke Purworejo mereka tinggal di Markas pejuang. Di Magelang pasukan sekutu melawan pasukan Republik. Terjadi pertempuran sengit, sampai Presiden Soekarno datang untuk melakukan perundingan. Sementara itu Bambang dan Tukijo kemudian bekerja di markas sebagai pembantu Mayor Hadrongi, mereka turut berjuang meskipun tidak memegang senjata. Suatu hari Pasukan Sekutu yang ada di Ambarawa menyerang pasukan Republik dengan menggunakan pasukan Jepang. Bambang dan Tukijo ikut dalam truk menuju Ambarawa. Pertempuran terjadi di Ambarawa. Pasukan republik berhasil mendesak pasukan sekutu di Ambarawa. Jendral Sudirman, komandan divisi Purwokerto datang dan memimpin pertempuran. Sekutu terjepit. Mulai tanggal 11 Desember serangan demi serangan dilancarkan. Sampai pada akhirnya tanggal 15 Desember pasukan Sekutu mampu ditundukkan oleh pasukan Republik atas pimpinan Jendral Sudirman.

Kombinasi konvensi budaya yang spesifik sebagai pola dapat dipahami dalam novel Pertempuran Ambarawa karya A. Soeroto. Novel menampilkan peristiwa penjajahan di daerah Jawa Tengah yakni Semarang, Magelang, dan Ambarawa sesuai dengan kisah nyata sejarah kolonial di Indonesia yang terjadi pada tahun 1945. Ambarawa menjadi daerah pertempuran yang penting dalam sejarah kolonial melawan sekutu yang sebelumnya telah mengalahkan Jepang di masa setelah kemerdekaan di proklamirkan yakni sekitar Oktober sampai Desember 1945. Pasukan sekutu yang kemudian berbalik menyerang pasukan Republik didesak oleh pasukanpasukan Republik dari daerah-daerah di sekitar Ambarawa. Faktor terpenting dalam penyerangan itu adalah sosok Jenderal Sudirman yang sebelumnya adalah komandan divisi Purwokerto yang kemudian menjadi pemimpin pasukan Republik melawan pasukan Sekutu. Dengan strategi-strategi perang Jenderal Sudirman pasukan sekutu berhasil didesak dan akhirnya dilumpuhkan. Tak kalah penting dalam cerita ini adalah mengenai dua orang sahabat yakni Bambang dan Tukijo. Secara garis besar novel ini menceritakan mengenai perjalanan Bambang dan Tukijo yang sebelumnya adalah korban kolonial yang berhasil menyelamatkan diri keluar dari Semarang dan diselamatkan oleh pasukan Republik, hingga akhirnya menjadi pembantu di markas pasukan Republik dan turut serta dalam berperang melawan sekutu di bawah pimpinan Jendral Sudirman di Ambarawa.

Kisah sejarah kolonial sebagai formula sangat mendukung struktur novel dengan konvensi dan invensi yang berkesinambungan dengan konteks yang ada. Di dalam novel Pertempuran Ambarawa dapat dilihat adanya aspek 
sejarah bagaimana jalannya perang di Ambarawa yang dipimpin Jenderal Sudirman. Peristiwa sejarah di masa kolonial ini tentu menjadi unsur utama, kendati sudut pandang yang digunakan adalah kisah perjuangan dua orang sahabat yang masih berusia muda untuk turut serta bertempur melawan kolonial. Unsur kisah perjuangan melawan kolonial masuk dalam genre sejarah, yang dipandang dari sudut pandang remaja atau pemuda sebagai tokoh sentral penceritaan terkait dengan tema besar yang diangkat pengarangnya. Alur kisah ini pun secara jelas digambarkan dengan gradasi yang tidak bisa dikatakan sederhana, walaupun kemasan ceritanya tergolong sederhana karena ditujukan sebagai buku materi pendidikan di sekolah dengan sasaran siswa sekolah dasar hingga sekolah menengah. Namun demikian dari awal cerita, konflik, dan klimaksnya sudah dapat ditebak bahwa kisah ini akan happy ending.

Hal-hal yeng sebelumnya tak disadari dan dimunculkan yaitu kisah orang-orang yang tidak pernah tercatat dalam sejarah dalam kisah-kisah perjuangan kemerdekaan Indonesia melawan kolonial. Dapat dilihat sistem konfensional dalam menstrukturkan produk budaya melalui konflik antara pasukan Republik dengan pasukan kolonial sebagai inti permasalahan yang diangkat, representasi tokoh-tokoh dalam kisah sejarah yang sesungguhnya dalam hal ini Jendral Sudirman, perwatakan tokoh yang penuh dengan nilai-nilai terpuji sebagai pejuang, tema sejarah kolonial, dan juga penyelesaian atau akhir yang membahagiakan. Unsur-unsur tersebut merupakan unsur-unsur yang tersusun menjadi sebuah struktur sederhana pembangun cerita dalam melihat genre dan merumuskan jenis genre tersebut dalam karya sastra.

Novel kedua yang dikaji adalah Sulawesi Berdarah karya Saadi AS.
Novel ini menceritakan kisah setelah proklamasi kemerdekaan 17 Agustus 1945. Berita kemerdekaan sampai di kota Makassar. Dua orang tokoh yakni Dr. Ratulangi dan Audi Sulthan telah kembali dari Jakarta. Tentara Jepang telah menyerah. Robert Wolter Monginsidi, seorang pelajar yang memiliki cita-cita sangat tinggi adalah tokoh remaja di SMP Nasional yang didirikan oleh Dr. Ratulangi. Robert dan teman-temannya di SMP Nasional sebagai markas besar para pelajar menyebarkan berita kemerdekaan Indonesia dari Dr. Ratulangi. Tanggal 19 Agustus 1945 bendera merah putih dikibarkan dan digelar upacara perayaan kemerdekaan. Dr. Ratulangi pemimpin Makassar mulai menata kembali kehidupan rakyat. Suasana di kota dan desa pulih kembali. Namun, ketentraman itu kembali hiruk-pikuk ketika sebuah pesawat mendarat di Sulawesi Selatan. Pesawat Sekutu datang tanggal 24 September 1945 dengan dalih akan melucutu persenjataan pasukan Jepang. Tapi hal yang sesungguhnya diketahui oleh rakyat Indonesia bahwa mereka datang dengan misi NICA. Pasukanpasukan Belanda dari laut dan udara mendarat di Sulawesi. Seketika pasukan Belanda beraksi, suasana Sulawesi menjadi genting.

Lantas dibentuklah KRIS Muda (Gerakan Pemuda Indonesia Sulawesi) oleh Audi Kalang. Perlawanan Pemuda Sulawesi tak diduga oleh Belanda. Belanda kemudian menyerang penduduk. Robert bersama-teman-temannya pun bergrilya. Hingga dia menjadi salah satu orang yang diburu Belanda. November 1945 laskar pemuda bergrilya, bertepur melawan Belanda. Robert terluka sehingga harus ditandu. Belanda kalah dalam pertempuran itu dan pada suatu ketika Belanda balas dendam. 29 tentara grilya tertangkap dan dibunuh dihadapan rakyat oleh Kapten Westerling. Awal 
Desember LAPRIS melakukan perlawanan. Kapten Westerling sangat marah dan membantai penduduk, termasuk pemimpin Laskar TRATEA Daeng Ngoro. Setiap sudut Sulawesi dibantai. Kekejaman itu berlangsung dari pertengahan Desember 1946 sampai awal tahun 1947.

Para pemuda grilya, dipimpin Robert menyusun strategi perlawanan. Tapi sial, mereka tertangkap tentara Belanda, Robert pun dipenjara. Namun, ketika tahu bahwa gadis yang dicintainya telah dihabisi oleh tentara Belanda, Robert pun bergejolak. Robert akhirnya berhasil melarikan diri dari penjara, namun, lagi-lagi tertangkap. Bertahuntahun Robert dipenjara. Sementara Sumatra dan Jawa sudah benar-benar merdeka, tapi Indonesia Timur belum. Indonesia Timur menjadi negara Boneka di bawah kekuasaan Belanda. Sulawesi mendapat dukungan dari seluruh daerah di Indonesia bahwa sebagai bagian dari Indonesia Sulawesi dan Indonesia Timur harus benar-benar merdeka. Tanggal 5 September 1949 Robert Wolter Monginsidi dihukum mati.

Di dalam novel ini dapat dilihat kisah sejarah di masa kolonial, yakni penjajahan di daerah Sulawesi, bagian Indonesia Timur yang terjadi pada tahun 1945 sampai 1949. Sulawesi sebagai bagian dari Indonesia Timur pascaproklamasi kemerdekaan didatangi sekutu yang bekerjasama dengan Belanda yang kemudian menduduki kembali wilayah Indonesia Timur dan membuat Negara Boneka. Terjadilah grilya oleh para pemuda yang menginginkan kemerdekaan seutuhnya. Faktor terpenting dalam penyerangan itu adalah sosok Robert Wolter Monginsidi, salah satu pahlawan Sulawesi. Tak kalah penting dalam cerita ini adalah mengenai Supit, teman Robert di SMP Nasional milik Dr. Ratulangi. Secara garis besar novel ini bercerita mengenai perjuangan
Robert sebagai pasukan grilya, pasukan Republik pembela Tanah Air hingga ia mati.

Formula salam novel Sulawesi Berdarah, terlihat adanya kesamaan dengan novel Pertempuran Ambarawa. Secara struktur, formula yang muncul adalah konvensi dan invensi berkaitan dengan tragedi pascakemerdekaan, perjuangan para pemuda, tekanan dari kolonial, latar daerah, tokoh, dan akhir cerita yang dalam novel ini tidak bahagia. Novel ini memiliki kecenderungan kisah yang dominan mengenai perjuangan Robert Wolter Monginsidi, namun, bukan berarti kisah ini adalah kisah biografi seorang tokoh. Secara keseluruhan cerita yang dibangun adalah mengenai perjuangan pasukan grilya di Sulawesi.

Melihat kecenderungan dalam dua novel terbitan Balai Pustaka tahun 1970an tersebut tampak adanya kecenderungan yang kesamaan dan perbedaan atas keduanya. Artinya, dalam situasi ini novel sebagai karya sastra menjadi sebuah ruang untuk mengemas sebuah kisah sejarah yang pernah terjadi di masa kolonial. Oleh karena itu genre sejarah menjadi sebuah sistem konvensional dalam menstrukturkan produk budaya terkait dengan sasaran pembaca novel ini sebagai media pendidikan di sekolah-sekolah di Indonesia. Sejarah masa kolonial menjadi sebuah cerita yang jika dikemas secara apik nilai-nilai perjuangan peningkatan moral manusia, keluhuran budi, dan perikemanusiaan sejagat, atau apa yang disebut sebagai humanisme universal dapat dijadikan sebagai bahan pembelajaran kehidupan. Kesamaan yang muncul dalam kedua karya terbitan Balai Pustaka tersebut adalah sebuah contoh mengenai semangat perjuangan pemuda memperjuangkan kemerdekaan Indonesia dengan melawan penjajah. 
3.2 Formula Novel Anak Genre Sejarah Terbitan Balai Pustaka Tahun 1980-an

Novel Lembah di Kaki Bukit (1983) karya Muh. Sunardiyanto dan novel Pejuang-pejuang Ulet di Lereng Sumbing (1985) karya Suprapto HP secara garis besar dapat dilihat bahwa keduanya menggunakan formula-formula yang sama dengan novel terbitan Balai Pustaka periode 1970-an. Namun, untuk lebih jelasnya berikut sinopsis kedua novel tersebut:

Novel Lembah di Kaki Bukit karya Muh. Sunardiyanto menceritakan kisah Penjajahan Belanda yang menerapkan monopoli dagang, tanam paksa dan halhal licik lainnya. Belanda memecah kedamaian melalui Keraton Mataram. Pangeran Diponegoro menggembleng laskarnya di beberapa desa, di antaranya adalah desa Dukuhreja. Pemuda-pemuda yang kekar tubuhnya nantinya akan menjadi pasukan perang melawan Kompeni Belanda. Pangeran Diponegoro bersama Kyai Maja sering bertandang ke rumah Kyai Abdurrahman untuk melatih pencak silat pkepada para pemuda termasuk juga anak Kyai Maja, yakni Ahmad Nawawi.

Semakin hari Belanda semakin menjadi. Kerajaan Yogyakarta pun disetir oleh Belanda. Kerajaan-kerajaan di Jawa menjadi terpecah belah karena politik adu domba. Kekayaan kerajaan banyak yang diambil Belanda. Melihat hal itu Pangeran Diponegoro mengambil sikap untuk melakukan perlawanan terhadap Belanda. Tahun 1825 Belanda membuat jalan untuk menghubungkan Yogyakarta dengan Magelang. Pekarangan Rumah Pangeran Diponegoro tak luput dari proyek itu. Maka Pangeran Diponegoro mencabuti patok bakal jalan itu. Belanda marah, dan pecahlah Perang Diponegoro 1825 sampai 1830. Didukung para ulama Pangeran Diponegoro bertambahlah pasukannya. Karena keterbatasan peralatan perang Pasukan Pangeran Diponegoro berperang dengan cara gerilya.

Perang semakin luas, pembakaran, perusakan tanaman tebu Belanda, dan korban berjatuhan di mana-mana. Nawawi sebagai pemuda memimpin pasukan Diponegoro hingga kompeni Belanda kalah. Keberanian Nawawi dielu-elukan warga Dukuhreja. Perlawanan pasukan Diponegoro membuat keder Belanda yang kemudian mendatangkan bantuan. Perang semakin luas tidak hanya di Yogyakarta, bahkan hampir di seluruh Jawa Tengah. Belanda membangun benteng stensel di manamana untuk memperkuat pertahanan. Untuk melawan keahlian memainkan pedang pasukan Diponegoro Belanda mengajukan Loui Van Pasth yang lihai bermain pedang. Ditengah perang, Van Pasth datang di area pertempuran menarik pasukannya. Dalam masa rehat perang itu Nawawi dan Badriyah pun menikah. Nawawi yang baru menikmati hari-hari pernikahan harus turun ke medan perang karena pasukan Belanda menyerang pasukan Diponegoro di Deksa dipimpin Loui Van Pasth. Di tengah peperangan Nawawi diselamatkan oleh Badriyah yang dikiranya Komaruddin. Badriyah terhunus punggungnya oleh Van Pasth sebelum kemudian Van Pasth terpenggal kepalanya oleh sabetan Nawawi. Setelah perang usai barulah Nawawi tahu bahwa yang menyelamatkannya adalah Badriyah yang menyusul Nawawi dan kemudian gugur di medan perang.

Cerita novel Lembah di Kaki Bukit ini memperlihatkan gambaran mengenai sejarah perang Diponegoro di Yogyakarta dan Jawa Tengah yang terjadi tahun 1825 sampai 1830 yang mengakibatkan banyaknya korban yang berjatuhan. Formula yang mengkombinasikan konvensi budaya 
memiliki kesamaan dalam tema novelnovel anak terbitan Balai Pustaka. Yang membedakan novel ini dengan dua novel yang dibahas sebelumnya yakni cerita ini memiliki latar waktu kejadian di masa sebelum kemerdekaan. Perbedaan lain adalah komposisi formula yang berakhir dengan bahagia sekaligus sedih, selain itu unsur-unsur yang muncul adalah kisah semangat pemuda, keikutsertaan pemuda dalam perang melawan kolonial, kelicikan penjajah, konflik antara penjajah dengan tentara republik, dan akhir yang tragis. Ada hal yang menarik dalam kisah ini, bahwa ada bumbubumbu kisah percintaan antara Badriyah dan Nawawi yang juga menarik. Namun demikian kisah yang lebih mendominasi adalah mengenai perjuangan tentara pasukan Diponegoro dalam mealwan Belanda.

Dari aspek-aspek tersebut pengarang terlihat menggunakan sudut pandang penceritaan yang menarik dengan alur yang jelas dan memberikan suatu nilai-nilai yang lain di dalam cerita. Ada kejutan-kejutan yang menyimpan nilai-nilai peningkatan moral manusia, keluhuran budi, dan rasa humanisme universal yang dapat dijadikan sebagai bahan pembelajaran kehidupan. Adanya kekuatan nilai ideologis yang ditanamkan terkait dengan cerita perang Diponegoro dalam tokoh-tokoh yang dibangun, seperti Pangeran Diponegoro sendiri, Nawawi, Badriyah, Samingun, dan Bandi. Semua tokoh tersebut seolah menjadi tokoh sentral dalam cerita, namun demikian dario awal sudah jelas diarahkan bahwa sesungguhnya tokoh utama dalam novel ini adalah Badriyah.

Novel anak terbitan Balai Pustaka tahun 1980-an selanjutnya adalah Pejuang-pejuang Ulet di Lereng Sumbing, karya Suprapto HP. Serdadu Belanda datang kembali ke Indonesia membonceng pasukan sekutu setelah Indonesia memproklamasikan kemerdekaannya tanggal 17 Agustus 1945. Adalah Pak Kusworo pemimpin pasukan tentara Republik di wilayah lereng Sumbing. Untuk memenuhi kebutuhan tentara Republik ia menjual kambing bantuan rakyat. Pak Ali penjual kambing yang juga rekan Pak Kusworo adalah orang yang senantiasa dimintai bantuan untuk menjual kambingkambing itu ke kota. Bersama Pendek, anaknya, Pak Ali menjual empat kambing pak Kusworo ke kota. Di perjalanan ia berjumpa dengan tentara serdadu Belanda, mereka membeli kambing-kambing dagangan Pak Ali dan memintanya membawa ke markas. Sikap baik ditunjukkan serdadu Belanda. Beberapa kali Pak Ali diminta mengantarkan kambing-kambing ke Markas dan ditukar dengan kebutuhan logistik yang nantinya akan digunakan untuk persediaan perbekalan tentara Republik.

Suatu ketika di markas Belanda, Pak ali bertemu dengan Pardi. Pardi adalah seorang pribumi yang menjadi serdadu Belanda. Dulunya dia adalah teman berjualan kambing Pak Ali. Di situ Pardi menitipkan surat untuk Pak Kusworo komandan tentara Republik. Belakangan diketahui bahwa ia adalah adik dari Pak Kusworo yang sejak kecil pergi tanpa pamit. Dalam surat Pardi mencoba memberikan informasi keberadaannya kepada Pak Kusworo dan meminta untuk segera menyerang maskas belanda. Sampai pada suatu waktu Pak Kusworo bersama pasukannya menyerang maskar dan Pardi membebaskan tentara republik yang menjadi tawanan perang dan Belanda Terpojok. Pardi melarikan diri bersama dengan pasukan Republik. Ia menuju rumah Pak Ali. Dan kemudian Pardi dipertemukan dengan Pak Kusworo, kakaknya. Pasukan Republik pun melakukan gencatan senjata mengusir Belanda yang kembali menduduki 
Indonesia yang sudah dinyatakan merdeka. Pasukan Republik merangsek menguasai kota Parakan, dan tentara Belanda ditarik kembali ke negaranya.

Pada novel Pejuang-pejuang Ulet di lereng Sumbing tersebut, memiliki kesamaan dengan novel-novel sebelumnya, yakni mengangkat peristiwa yang terjadi selepas proklamasi kemerdekaan. Kekhasan yang muncul sama dengan dua novel terbitan Balai Pustaka tahun 1970-an. Sebuah kisah sejarah yang terjadi di Jawa Tengah, tepatnya di Temanggung, lereng Sumbing. Dilihat dari cerita yang disampaikan, kisah ini mengangkat tokoh-tokoh yang (mungkin) tidak pernah tercatat dalam sejarah. Peristiwa kembalinya kolonial belanda setelah pasukan sekutu menyerang Jepang, Belanda yang kembali memberikan tekanan, dan perjuangan mempertahankan kemerdekaan menjadi inti dari cerita Pejuang-pejuang Ulet di Lereng Sumbing ini. Sama dengan novel Pertempuran Ambarawa dan Sulawesi Berdarah, novel ini memperlihatkan sudut pandang lain lain dalam sebuah perjuangan merdeka. Bagaimana peran perjuangan rakyat dan tentara republik dikisahkan, dan ditonjolokan sebaga inti cerita. Seorang tokoh anak-anak yang memiliki keberanian dalam menyikapi sebuah penjajahan.

Jika dibandingkan secara struktural, antara novel Pejuang-pejuang Ulet di Lereng Sumbing karangan Suprapto HP. Dengan novel Lembah di Kaki Bukit karya Muh. Sunardiyanto sebagai karya yang terbit tahun 1980-an terdapat beberapa perbedaan dalam cerita yang diangkat. Muh. Sunardiyanto lebih menonjolkan perang yang terjadi dalam masa sebelum proklamasi kemerdekaan, yakni Perang Diponegoro. Meskipun dalam konteks yang berbeda namun genre sejarah tetap menjadi tema utama dalam novel-novel Balai Pustaka tersebut. Secara struktur novel ini memiliki kesamaan dengan Pertempuran Ambarawa karya A. Soeroto di mana ceritanya happy ending.

Kesadaran dalam mengangkat isu perjuangan-perjuangan yang tak tercatat sejarah ini menjadi menarik untuk didalami. Wacana besar yang secara struktur berpijak dari kondisi kolonial di Indonesia yang meninggalkan kenangan pahit maupun kenangan manis yang penuh dengan semangat kegigihan memperjuangkan tanah air dengan hanya memiliki saru harapan yakni merdeka. Semangat inilah yang kemudian ditawarkan kepada para pelajar dan pemuda Indonesia hari ini dan kesemuanya hidup dalam konteks dan ruang berbeda, namun secara genre mampu disatukan ke dalam satu benang merah yang sama, persoalan sejarah. Melihat kecenderungan dalam dua novel terbitan Balai Pustaka tahun 1980-an tersebut tampak adanya kecenderungan yang berbeda atas keduanya. Artinya, tradisi penulisan kisah sejarah sesuai dengan aturan konvensional masih tetap dipertahankan. Namun demikian dapat dilihat dalam novel Lembah di Kaki Bukit terdapat inovasi-inovasi yang memberikan kejutan-kejutan yang membuat novel ini menjadi berbeda dengan novel terbitan 1970-an dan juga dengan novel Pejuang-pejuang Ulet di lereng Sumbing dengan yang diterbitkan pada periode yang sama. Sejarah kolonial menjadi sebuah cerita yang jika dikemas secara apik nilai-nilai perjuangan peningkatan moral manusia, keluhuran budi, dan perikemanusiaan sejagat, atau apa yang disebut sebagai humanisme universal dapat dijadikan sebagai bahan pembelajaran kehidupan terutama sekali untuk membentuk karakter Indonesia yang ditanamkan kepada generasi muda bangsa ini. Nilai-nilai semangat perjuangan pemuda memperjuangkan kemerdekaan Indonesia melawan 
kolonial tentu akan memupuk semangat nasionalisme berbangsa dan bernegara.

\subsection{Formula Novel Anak Genre Sejarah Terbitan Balai Pustaka Tahun 1990-an}

Novel-novel anak genre sejarah terbitan Balai Pustaka periode tahun 1990-an, yang dikaji dalam kajian ini adalah Wonakaka (1993) karya Djoko Dwinanto dan Pejuang Kecil di Bumi Irian (1996) karya Bagin. Apakah kedua novel ini mengandung kekhasan yang sama dengan novel terbitan Balai Pustaka periode 1970-an dan 1980-an?

Novel Wonakaka bercerita tentang perjuangan rakyat Kodi, Sumba Barat melawan Kolonial Belanda yang dipimpin oleh rajanya yakni Wonakaka. Hal itu terjadi tahun 1980. Belanda yang dipimpin Residen Timor masuk ke daerah Kodi. Sama dengan yang diulakukan di Jawa. Residen Timor membuka jalan dengan dalih persahabatan dengan raja Kodi untuk memperlancar hubungan dagang. Rakyat Kodi yang dipimpin oleh Rato Raya tahu dengan hal itu. Hal tersebut pasti adalah kelicikan Belanda untuk menguasai Kodi. Surat undangan dari Residen Timor Pun diterima. Setelah berunding lama akhirnya rakyat Kodi yang dipimping oleh Rato Hamba Dondo datang ke Pesanggrahan Residen. Rato Raya tidak ikut. Rayuan-rayuan Residen Timor dilancarkan, Notolaksono, seorang Jawa yang ketika itu berperan sebagai penasihat Rato Hamba Dondo tidak bisa berbuat apa-apa. Akhirnya dengan penuh keraguan Rato Hamba Dondo menandatangani surat perjjian persahabatan dari Residen Belanda. Dengan Begitu Belanda pun leluasa untuk keluar masuk Kodi dalam rangka berdagang.

Pasukan Belanda pun semakin bnayak. Kelicikan-kelicikan Belanda semakin terlihat. Rakyat banyak yang dirugikan. Hasil bumi mereka dipaksa dibeli dengan harga murah, tak jarang pemaksaan-pemaksaan dilakukan dan terjadilah penganiayaan. Rato Hamba Dondo yang kini sidah dinobatkan menjadi raja oleh Rato Raya merasa menyesal atas perbuatannya telah menandatangani surat perjanjian persahabatan itu yang berakibat kesengsaraan rakyat. Di samping itu di Kodi Bokol diangkatlah Raja Lohge Kedua. Dari hal itu tak jarang terjadi adu domba Belanda terhadap kedua kerajaan sehingga Kodi menjadi terpecah. Semakin lama keberadaan Belanda di Kodi semakin menyengsarakan rakyat. Rakyat dipekerjakan secara paksa untuk membangun jembatan-jembatan dan jalan-jalan. Rato Hamba Dondo meraja semakin marah. Dengan meminta bertimbangan dari ayahnya dan Notolaksono selaku orang yang dituakan, ia ingin menyerang Belanda. Rato Lohge Kedua pun merasakan hal yang sama. Lantas ia mengirim surat kepada Rato Hamba Dondo untuk bersatu bersamasama melawan Belanda. Bangsawanbangsawan Kodi dikumpulkan, sebuah rencana besar telah disusun untuk melawan Belanda. Penyerangan pun dilancarkan. Residen Timur marah. Beberapa orang Kodi ditangkap. Selain itu ia membangun benteng-benteng pertahanan.

Seorang pemuda desa, ahli tembak, dialah Wonakaka. Pati Manakoha dari kerajaan mendengar kehebatan pemuda itu. Dia meminta Wonakaka untuk bergabung dengan pasukan dan melawan Belanda. Dadanya bidang, tubuhnya tegap, matanya tajam sekarang sudah siap menjadi pasukan perang untuk melawan Belanda. Peranag pun dilancarkan. Wonakaka tampak gigih berjuang melawan kolonial belanda. Namun dengan keadaan pasukan dan persenjataan yang minim, pasukan Kodi mundur. Tapi hal itu tidak berhendi 
begitu saja, Dendam dan kemarahan Wonakaka semakin memuncak. Benteng tepat pertahanan diserbu pasukan Belanda. Suatu hari Wonakaka di lokasi persembunyian yang lain mengumpulkan pasukannya. Ia berencana memasang jebakan untuk pasukan Belanda. Parit digali, jerami kering diletakkan di atasnya. Prajurit Wonakaka bersembunyi disitu untuk menghadang pasukan Belanda. Dan rencana itu berhasil, mereka berhasil melumpuhkan pasukan belanda dari jarak dekat.

Tahun sudah berganti hingga 1912. Sudah empat tahun Belanda bercokol di Kodi. Siasat-siasat perang pun terus dilakukan oleh pasukan Kodi untuk melumpuhkan Balanda. Istri Wonakaka pun tewas dalam sebuah pertempuran. Semenjak itu Wonakaka mengurangi kegiatannya. Wonakaka menjadi incaran Belanda, tetapi ia cukup cerdik untuk menghindar. Pasukan Belanda pun menyusun strategi. Belanda sering melakukan patroli. Sampai pada akhirnya Belanda berhasil melakukan tipu muslihat terhadap Kodi. Para pemuda dihimpun untuk berjuang. Peperangan kembali terjadi, dan Wonakaka beserta beberapa pemuda tertangkap. Rato Loghe Kedua juga tertankap. Perang Wonakaka berakhir. Dia akhirnya mati di penjara.

Di dalam novel Wonakaka formula yang dibangun sama dengan novel Sulawesi Berdarah yang juga mengangkat salah satu tokoh pahlawan daerah yang mungkin sampai hari ini tidak dikenal. Hal itu mencerminkan bahwa novel ini sama dengan novelnovel sebelumnya. Genre sejarah novel menonjolkan kisah perjuangan melawan penjajah Belanda di sebuah daerah yakni Kodi, Sumba Barat para tahun 1900-an. Kisah perjuangan, rasa cinta tanah air, sikap nasionalisme yang sama dengan apa yang dilakukan oleh pasukan perang melawan kolonial di dalam Perang Aceh, Perang Padri, Perang Diponegoro dan peperangan-peperangan lainnya yang terjadi sebelum tahun itu. Kolonial Belanda menjadi musuh utama pasukan pribumi, dan dari situ sikap berbangsa dan kebersamaan rakyat terjajah memunculkan suatu resistensi atas kolonial dan memberikan nilai-nilai semangat perjuangan dalam kisahkisahnya. Perjuangan kecil ini dianggap memiliki struktu yang sama dengan kisah pada novel Sulawesi Berdarah yang pada akhir ceritanya tokoh utama dipenjara dan mati. Hal ini juga mengingatkan pada Perang Diponegoro yang memiliki kecenderungan yang sama dengan kisahkisah tersebut. Tidak ada kejuatan selain informasi yang khas yang memberikan bantuan berupa respon yang berubah dan memberikan informasi baru tentang dunia lain seputar perjuangan kemerdekaan.

Novel selanjutnya adalah novel Pejuang Kecil di Bumi Irian karya Bagin. Tahun 1960, sudah 15 tahun Indonesia merdeka, tapi kemerdekaan itu tidak untuk bumi Irian. Bulan April di tahun 1960 itu Irian masih merayakan hari lahirnya Raja Belanda, Ratu Yuliana. Semua sekolah, semua kantor, tangsi polisi dan militer, rumah penjara, di Irian Jaya mengadakan upacara besar-besaran untuk hari itu. Tahun 1960 New Guinea yang waktu itu berubah nama menjadi Irian Jaya masih dijajah Belanda. Kawon, seorang anak sekolah dasar yang mengikuti upacara hari itu merasa gelisah, tahu bahwa Irian Jaya adalah bagian dari Indonesia yang seharusnya sudah merdeka seperti daerah-daerah lain di Indonesia.

Tanggal 14 Mei Kawon ditahan karena menyanyikan lagu Indonesia Raya. Di Irian Jaya tidak boleh ada yang menyanyikan lagu Indonesia Raya. Lagu kebangsaan mereka adalah Wilhelmus, lagu kebangsaan Belanda. Usia Kawon masih dua belas tahun dan di penjara menjadi tahanan termuda. Di sana ia 
bertemu para pejuang dari organisasi untuk Membebaskan Irian atau Persatuan Semangat Pemuda 1945 yang dipimpin oleh Binyamin Falubun. 14 Agustus ia diadili dan dikeluarkan dari penjara, sesuai saran Binyamin Kawon mampir ke toko seorang Tiong Hoa, A Chong seorang tokoh pergerakan.

Tanggal 21 Agustus Kawon bersama tiga kawannya merayakan hari kemerdekaan Indonesia diladang ayahnya. Mereka berencana menyebarkan selebaran berisi teks lagu Indonesia Raya. Dengan hati-hati meleka melakukannya, ke rumah-rumah penduduk yang simpatik kepada Republik. Pengaruh dari hal tersebut banyak penduduk sambil mendayung perahu menyanyikan lagi Indonseia Raya. Tak lama terdengar desas-desus bahwa akan datang pasukan dari barat. Pasukan dari barat artinya adalah pasukan dari Republik Indonesia sebab Irian Jaya berada di wilayah timur Indonesia. Pasukan Belanda pun meningkatkan penjagaan. Kawon terus menjalankan misinya didukung oleh A Chong dan Damo, seorang pasukan Republik. Kawon dan Yeknon melakukan beberapa perundingan dengan ayahnya. Tanggal 10 oktober 1960 mereka ke kampung Benkopa. Di sana mereka memimpin orang kampung untuk menyanyikan lagu Indonesia Raya. Di situ Kawon menukarkan tembakau yang dibawanya dari A Chong kepada hasil bumi penduduk di setiap minggunya.

Bendera Merah Putih mulai berkibar. Namun yang terjadi kemudian, kampung-kampung yang mengibarkan bendera merah putih dibantai habishabisan oleh Belanda. Beberapa orang ditangkap, termasuk juga di kota Tanah Merah. Mereka dijebloskan ke penjara. Pada tanggal 10 November bertepatan dengan Hari Pahlawan, terjadi pemberontakan di penjara. Setelah hari itu Kawon sering ke penjara untuk menjenguk Binyamin Falubun. Tanggal 17 November penduduk melakukan penyerangan ke rumah penjara. Sel-sel tahanan dibuka. Namun sayang ketika Kawon hendak membuka sel Binyamin Falubun dia tertangkap dan kembali dimasukan ke penjara bersama pastor. Hingga datang pasukan Infantri Republik menyelamatkan mereka dan Kawon selanjutnya ikut bergrilya di hutan melawan Belanda.

Persoalan yang menarik terdapat dalam novel Pejuang Kecil di Bumi Irian ini. Hal ini menunjukan suatu berbedaan dari sudut pandang penceritaan dalam novel-novel sebelumnya. Jika pada novel-novel sebelumnya tokoh yang muncul di awal dan tokoh anak-anak tidak sebagai tokoh utama namun di dalam novel ini tokoh Kawon yang sejak awal di ceritakan terus menjadi fokus cerita. Ada kekhasan yang lain di dalam novel ini, kendati secara keseluruhan tema besar yang diangkat sama dengan novel-novel yang lainnya.

Komposisi formula cerita novel ini menyajikan gambaran arti yang sudah akrab bagi pebaca sebagaimana novelnovel sebelumnya. Hubungan nilai dalam novel-novel tersebut ditekankan sebagai konvensi yang menciptakan kestabilan budaya disamping invensi-invensi yang memberi respons dan informasi baru tentang dunia dalam novel tersebut. Semangat perjuangan melawan kolonial dan semangat nasionalisme secara empiris mendominasi keberadaan cerita. Nasionalisme, sebagai kesadaran bahwa usaha untuk memperoleh kemerdekaan di dalam sudut pandang penjajah akan dipandang sebagai kejahatan, pemberontakan, dan perlawanan. Namun demikian dalam sudut pandang koloni hal itu adalah kebaikan dan demi menegakkan kebenaran. Tokoh Kawon tampak mendominasi dalam novel ini. Bagaimana kegigihannya membangun relasi terhadap orang-orang dewasa 
sampai akhirnya menjadi bagian dari pasukan grilya melawan Belanda. Hal ini merupakan sesuatu yang berbeda dibanding kelima novel yang dibahas sebelumnya. Diketahui bahwa kisah ini merupakan fragmen terbentuknya Irian (sebutan dari Ir. Soekarno yang merupakan akronim dari Ikut Republik Indonesia Anti Nederland) di tahun 1960 sebagai bagian dari Indonesia yang berada di wilayah timur masih dijajah Belanda.

\section{Simpulan}

Dari novel anak Pertempuran Ambarawa (1976) karya A. Soeroto, Sulawesi Berdarah (1976) karya Saadi AS., Lembah di Kaki Bukit (1983) kaya Muh. Sunardiyanto, Pejuang-pejuang Ulet di Lereng Sumbing (1985) karya Suprapto HP., Wonakaka (1993) karya Djoko Dwinanto, dan Pejuang Kecil di Bumi Irian (1996) karya Bagin dapat diketahui dan dikenal para pahlawan daerah yang mungkin tidak tercatat atau tidak dikenal sebelumnya. Tentunya ada pengetahuan baru yang akan didapatkan setelah membaca novel-novel ini. Hal yang menarik adalah bahwa penulis-penulis novel ini sampai hari ini mungkin tidak pernah dikenal sebagai sastrawan, namanya tidak pernah disebut dalam pembahasan sastra, apalagi karyakaryanya. Kondisi tersebut merupakan sebuah fenomena, mengingat Balai Pustaka memiliki sejarah yang panjang dalam penerbitan buku-buku sastra yang melahirkan nama-nama sastrawan besar Angkatan Balai Pustaka. Persoalan mengenai sastra kanon atau tidak pada akhirnya menjadi tidak penting ketika isi muatan dari novel-novel tersebut lebih sebagai pengetahuan siswa-siswa di sekolah. Hal inilah kecenderungan yang terjadi dalam novel-novel anak terbitan Balai Pustaka.

Isu perjuangan kemerdekaan adalah bagian yang penting dalam rangka menemukan dan membaurkan identitas ke-Indonesia-an mutakhir, sebagai jejak kebudayaan dan sikap nasionalisme berbangsa dan bernegara. Kemajemukan masyarakat secara sosial, kultural dan budaya pascakolonial, mengarahkan bentuk semangat mengingat dan menemukan kembali potret-potret perjuangan yang dilakukan secara persoalan maupun ideologi oleh bangsa Indonesia di daerah-daerah. Hal tersebut beriring dengan perubahan dan orientasi dalam menciptakan semangat kebersamaan.

Novel-novel dengan genre sejarah (kolonial) terbitan Balai Pustaka ini memiliki formulasi dalam struktur novel antara satu dengan yang lain beragam, namun semuanya berkaitan dengan tema yang menjadi dasar, yaitu semangat perjuangan melawan kolonial. Formulasi mendasar ini menjadi faktor tambahan dalam melihat kecenderungan dan perubahan pola yang ada dari ketiga periode novel-novel bergenre sejarah terbitan Balai Pustaka. Pendekatan sejarah yang digunakan memperkuat novel-novel anak terbitan Balai pustaka sebagai fiksi-fiksi ciptaan yang bersifat generik. Persoalan teknis yang muncul dalam novel-novel tersebut adalah perbedaan kecenderungan penyelesaian masalah dari masing-masing periode dan pengarang. Sudah dapat ditebak bahwa novel-novel anak tersebut mengalami 'kegagalan' dengan menggunakan komposisi dan tema yang sudah klise.

Pendekatan sejarah yang menampilkan seleksi sumber-sumber data dan membuat interpretasi berdasar fakta-fakta yang diambil dari sumber yang berdasar atas paradigma tertentu. Di dalam novel-novel anak tradisi Balai Pustaka dapat dikatakan bahwa, dunia imajiner novel-novel Indonesia terbangun dari ketegangan antara dua dunia, yakni dunia ideal dan dunia nyata. Maksudnya, dunia ideal adalah situasi 
dan kondisi tempat terdapatnya persatuan antarsegala hal yang terpisah, terdapat keterbatasan yang memungkinkan seseorang mendapatkan kebebasan dan memungkinkan untuk menjadi apa saja, sedangkan dunia nyata adalah situasi dan konsisi tempat terdapatnya keterpecahan segala hal yang seharusnya tersatukan, terdapat keterbatasan yang menutup kemungkinan bagi seseorang untuk mendapatkan kemerdekaan dan untuk menjadi apa saja. Hal tersebut menunjukkan bahwa pada setiap zaman terdapat persoalan-persoalan yang memengaruhi keberadaan karya sastranya.

\section{Daftar Pustaka}

Saadi A.S. 1976. Sulawesi Berdarah. Jakarta: Balai Pustaka.

Adi, Ida Rochani. 2011. Fiksi Populer: Teori dan Metode Kajian. Yogyakarta: Pustaka Pelajar.

Bagin. 1996. Pejuang Kecil di Bumi Irian. Jakarta: Balai Pustaka.

Cawelti, John G. 1976. Adventure, Mystery, and Romance: Formula Stories as Art an Popular Culture. Chicago: University of Chicago Press.

Dwinanto, Djoko. 1993. Wonakaka. Jakarta: Balai Pustaka.

Eneste, Pamusuk. 1988. Ikhtisar Kesusastraan Indonesia Modern. Jakarta: Djambatan.

Faruk. 2007. Belenggu Pasca-Kolonial: Hegemoni dan Resistensi dalam Sastra Indonesia. Yogyakarta: Pustaka Pelajar.

Suprapto H.P. 1985. Pejuang-Pejuang Ulet di Lereng Sumbing. Jakarta. Balai Pustaka.

Mahayana, Maman S. 2012. Pengarang Tidak Mati: Peranan dan Kiprah Pengarang Indonesia. Bandung: Nuansa.
Rosidi, Ajip. 1964. Kapankah Kesusastraan Indonesia Lahir? Jakarta: Bhratara.

Soeroto, A. 1976. Pertempuran Ambarawa. Jakarta. Balai Pustaka.

Sunardiyanto, Muh. 1983. Lembah di Kaki Bukit. Jakarta: Balai Pustaka.

Sumardjo, Jakob. 1982. Novel Populer Indonesia. Yogyakarta: Nur Cahaya.

Wellek, Rene \& Austin Warren. 1995. Teori Kesusastraan. Diterjemahkan oleh Melani Budianta. Jakarta: Gramedia. 